\title{
Exocrine pancreatic function in children with coeliac disease before and after a gluten free diet
}

\author{
A Carroccio, G Iacono, G Montalto, F Cavataio, C Di Marco, V Balsamo, A Notarbartolo
}

\begin{abstract}
This study was designed to determine the extent of pancreatic insufficiency in untreated coeliac disease and whether pancreatic secretion is impaired after a prolonged gluten free period. Three groups of patients were studied: group A comprised 44 patients, mean (SD) age $4 \cdot 0(3 \cdot 1)$ years, with coeliac disease and total or subtotal atrophy of the intestinal mucosa; group B comprised 67 patients, mean age 4.4 (3.0) years, with coeliac disease but with normal morphology of the intestinal villi (after 12.9 months of a gluten free diet); group C comprised 49 control subjects, mean age 3.2 (3.0) years, with normal jejunal histology. In all subjects exocrine pancreatic function was determined by the secretin-caerulein test; bicarbonate concentration and lipase, phospholipase, and chymotrypsin activity were measured after an intravenous injection of secretin 1 clinical unit (CU)+caerulein $75 \mathrm{ng} /$ kg body weight. Faecal chymotrypsin concentration was also assayed. No significant difference was found between values of the duodenal output of pancreatic enzymes and bicarbonate obtained in the three groups; however, 10 of 44 untreated coeliac patients showed tryptic or lipolytic activity, or both, below the normal limit for our laboratory. The mean value of the faecal chymotrypsin concentration was significantly lower in untreated than in treated coeliac patients $(p<0.0001)$ or in control subjects $(p<0 \cdot 0001)$. It is concluded that untreated coeliac patients may have pancreatic deficiency independent of a decrease in enterohormone release. No primary or secondary pancreatic insufficiency was found in coeliac patients where the intestinal mucosa had returned to normal.
\end{abstract}

Medica, Università di Palermo

A Carroccio

G Montalto

C Di Marco

A Notarbartolo

Divisione Lattanti, Ospedale G Di Cristina, Palermo

G Iacono

F Cavataio

V Balsamo

Correspondence to:

Dr Guiseppe Montalto,

Istituto di Medicina Interna e
Int

Geriatria, via del Vespro 141,

90127 Palermo, Italy.

Accepted for publication

3 September 1990 exocrine pancreatic insufficiency has observed in untreated coeliac disease, ${ }^{1-6}$ which could reduce the benefits of a gluten free diet. In several studies it has been reported that this pancreatic secretion deficit is secondary to a decrease in enterohormone release due to the extensive intestinal damage; in particular, a slight increase in postprandial serum cholecystokinin $^{78}$ and a decrease in secretin release after duodenal $\mathrm{HCl}$ infusion ${ }^{10}$ have been observed in untreated coeliac patients. It has also been shown, however, that pancreatic function is directly impaired in conditions of prolonged malnutrition, ${ }^{11}$ and this might also determine a secretory deficit in patients with coeliac disease.

Furthermore, a deficit in enterohormone secretion ${ }^{12}$ and reduced urinary excretion of paraaminobenzoic acid (PABA) after the PABA test ${ }^{13}$ have also been reported in coeliac patients after a long period on a gluten free diet and after the histological normalisation of the intestinal mucosa.

The aims of the present study were (a) to determine to what extent pancreatic insufficiency which is not dependent on a decrease in enterohormone release affects enzyme secretion in untreated coeliac disease and (b) to determine whether, and to what extent, there is a prolonged deficiency in pancreatic secretion in coeliac patients after a long gluten free period.

\section{Patients}

Over the past three years 340 patients have been hospitalised in the department of paediatric gastroenterology for intestinal biopsy. After obtaining informed consent from their parents, we selected 160 subjects from among these patients who then underwent intestinal biopsy and a simultaneous pancreatic function test. The patients were divided into three groups according to the clinical diagnosis and histological examination of the intestinal mucosa: group A comprised 44 patients ( 15 boys, 29 girls), mean (SD) age $4 \cdot 0(3 \cdot 1)$ years (range 6 months-13 years), with coeliac disease and with total or subtotal atrophy of the intestinal mucosa; group B comprised 67 patients ( 37 boys, 30 girls), mean age $4.4(3.0)$ years (range 6 months-14 years), with coeliac disease but with normal morphology of the intestinal villi. These subjects underwent biopsy and pancreatic function tests from 9 to 15 months (mean 12.9 months) after a gluten free diet. The patients in groups A and B were diagnosed as having coeliac disease according to ESPGAN criteria ${ }^{14}$ at the end of three diagnostic phases.

Group C comprised 49 subjects ( 20 boys, 29 girls), mean age $3.2(3.0)$ years (range 6 months- 12 years), who were being investigated for short stature, but who were found to have normal jejunal histology. 


\section{Methods}

FAECAL CHYMOTRYPSIN DETERMINATION

On admission to hospital faecal chymotrypsin activity was determined at $37^{\circ} \mathrm{C}$ in two stool samples of approximately 5-10 g, collected on a standard diet in all patients, by a photometric assay (Monotest Chymotrypsin, Boehringer, Mannheim). ${ }^{15}$ The lower limit for the faecal chymotrypsin results (mean of the two estimations, each performed on $100 \mathrm{mg}$ of faeces) was arbitrarily fixed at $7 \cdot 5 \mathrm{U} / \mathrm{g}$ (mean value $-2 \mathrm{SD}$ in our laboratory, estimated on over 300 healthy control subjects).

\section{SECRETIN-CAERULEIN TEST}

Exocrine pancreatic function was determined in all patients by the secretin-caerulein test according to the method of Gullo et al. ${ }^{16}$ This test was performed simultaneously with intestinal biopsy using a modified version of the Taylor tube. ${ }^{17}$ The modification consisted of a small inflatable balloon for the occlusion of the pylorus to ensure a complete and exclusive collection of both gastric and pancreatic juice. The juices were aspirated at a continuous low pressure ( 33 to 50 $\mathrm{cm}$ water) with a suction pump. This examination was performed after an overnight fast; the tube was introduced into the stomach, and the distal end, under fluoroscopic control, was placed beyond the ligament of Treitz. The

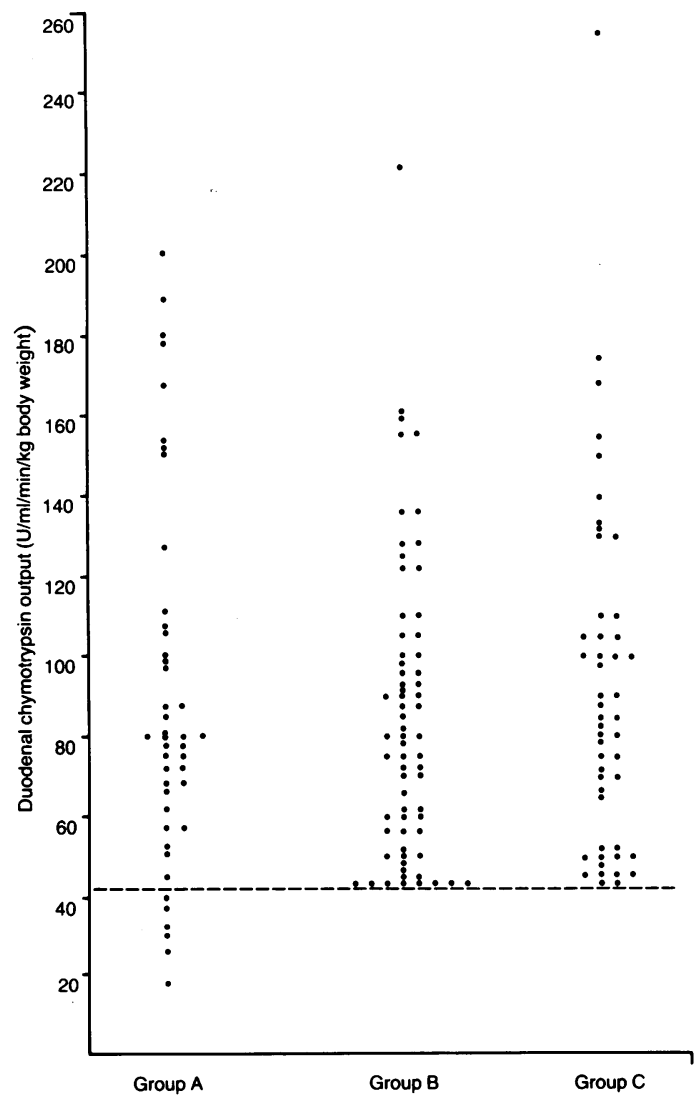

Figure 1: Individual duodenal chymotrypsin outputs (in one of two 15 minute samples after secretin +caerulein injection) expressed in units per ml per minute per kg body weight in the three groups. Group A: coeliac patients with total villous atrophy; group B: coeliac patients with normal intestinal villi; group C: control subjects. Dotted line=low normal limit.

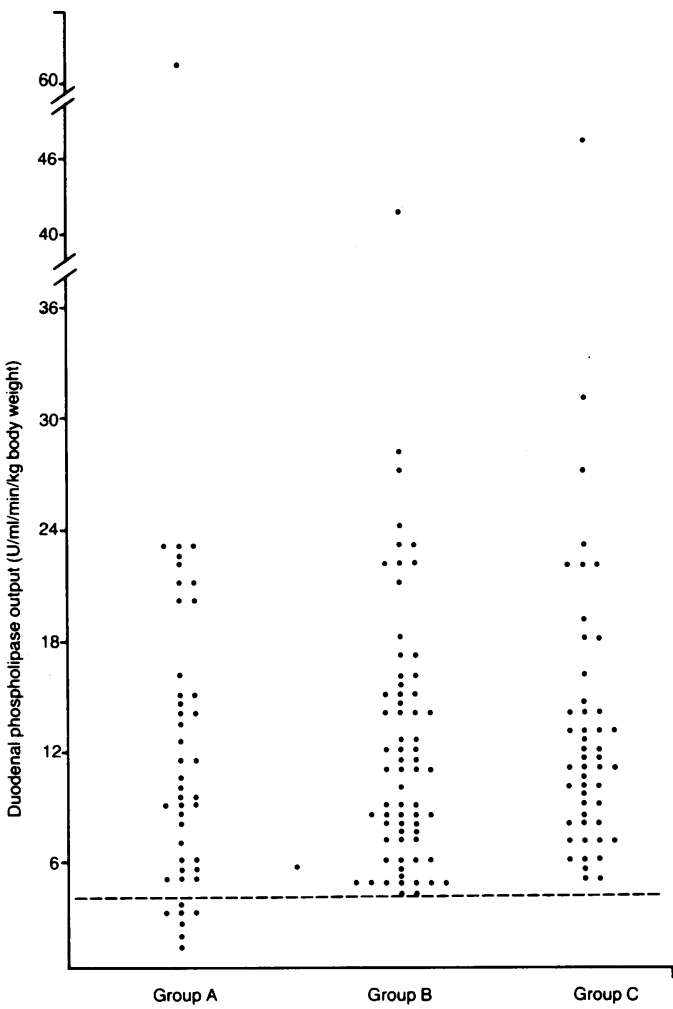

Figure 2: Individual duodenal phospholipase outputs (in one of two 15 minute samples after secretin + caerulein injection) expressed in units per ml per minute per kg body weight in the three groups. Group A: coeliac patients with total villous atrophy; group B: coeliac patients with normal intestinal villi; group C: control subjects. Dotted line $=$ low normal limit.

patient was then positioned on the left side and 2 $\mathrm{ml}$ of a $10 \mathrm{mg} / \mathrm{ml}$ solution of bromsulphalein was injected through the gastric tube so that the effectiveness of pyloric blockage could be checked throughout the experiment. Patients whose duodenal contents contained bromsulphalein were excluded from the study.

After a 15 minute basal collection period, secretin (Sekretolin, Hoechst, Germany) 1 clinical unit $(\mathrm{CU}) / \mathrm{kg}$ and caerulein (Takus, Farmitalia, I) $75 \mathrm{ng} / \mathrm{kg}$ were slowly injected intravenously and duodenal juice was collected into crushed ice during two 15 minute periods.

The parameters for the estimation of exocrine pancreatic function include volume, $\mathrm{pH}$, and bicarbonate measured by the back titration method (Methrom, Suisse); lipase activity was determined on olive oil emulsion in the presence of biliary salts ${ }^{18}$; phospholipase was assayed on

Mean (SD) values of duodenal enzyme and bicarbonate output after secretin-caerulein stimulation (in one of two 15 minute samples; the highest value is given) in patients with coeliac disease with total atrophy of the intestinal mucosa (group A) and with normal intestinal mucosa (group B) and in control subjects (group $C$ )

\begin{tabular}{|c|c|c|c|}
\hline & Group A & Group B & Group C \\
\hline $\begin{array}{l}\text { Chymotrypsin } \\
(\mathrm{U} / \mathrm{ml} / \mathrm{min} / \mathrm{kg})\end{array}$ & $89 \cdot 7(45 \cdot 9)$ & $84 \cdot 2(36 \cdot 8)$ & $91 \cdot 4(43 \cdot 1)$ \\
\hline $\begin{array}{l}\text { Phospholipase } \\
\text { (U/ml/min } / \mathrm{kg} \text { ) }\end{array}$ & $12 \cdot 6(9 \cdot 9)$ & $12 \cdot 1(7 \cdot 0)$ & $13 \cdot 0(7 \cdot 4)$ \\
\hline $\begin{array}{l}\text { Lipase } \\
(\mathrm{U} / \mathrm{m} \mathrm{l} / \mathrm{min} / \mathrm{kg})\end{array}$ & $829 \cdot 9(855 \cdot 1)$ & $655 \cdot 8(343 \cdot 2)$ & $789 \cdot 1(338 \cdot 8)$ \\
\hline $\begin{array}{l}\text { Bicarbonate } \\
(\mathrm{mEg} / \mathrm{ml} / \mathrm{kg})\end{array}$ & $47 \cdot 2(25 \cdot 2)$ & $43.9(16 \cdot 3)$ & $49 \cdot 7(21 \cdot 3)$ \\
\hline
\end{tabular}

None of the differences were significant. 


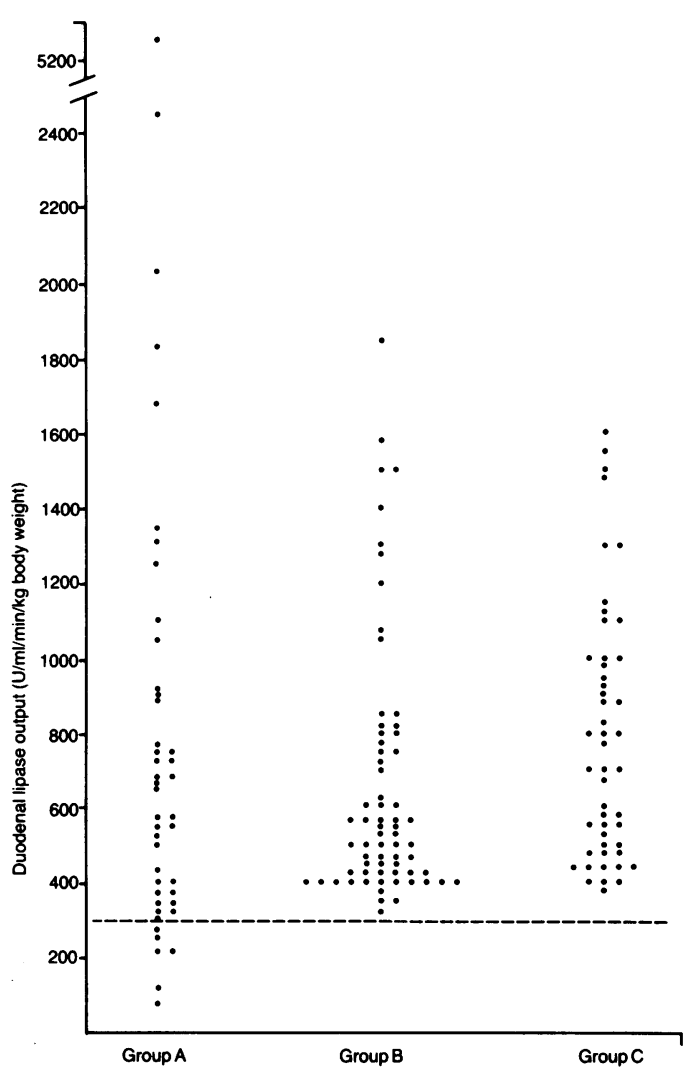

Figure 3: Individual duodenal lipase outputs (in one of two 15 minute samples after secretin + caerulein injection) expressed in units per ml per minute per kg body weight in the three groups. Group A: coeliac patients with total villous atrophy; group B: coeliac patients with normal intestinal villi; group C: control subjects. Dotted line =low normal limit.

egg yolk emulsion according to Figarella and Ribeiro ${ }^{19}$; chymotrypsin was assayed on its specific substrate, ATEE. $^{20}$ Bicarbonate and all enzyme activities were measured immediately after collection. The enzyme assay yielded results in units/ml juice. They were converted to give units $/ \mathrm{minute} / \mathrm{kg}$, corrected for the volume output and the size of the child; this correction was also made to calculate bicarbonate output.

The lower limit for bicarbonate and duodenal enzyme results was arbitrarily estimated equal to the lowest value obtained in our laboratory on over 100 healthy subjects in the same age range as that of the patients studied. Reference values (U/min/ $\mathrm{kg}$; volume output in 15 minutes) in our laboratory for infants weighing at least $6 \mathrm{~kg}$ : chymotrypsin output (mean (SD)) 95.3 (44.7), range 42-285; phospholipase 13.3 (9.2), 4-65; lipase $890(800), 300-5450$. Bicarbonate output was $46(32) \mathrm{mEq} / \mathrm{ml} / \mathrm{kg}$, range $13-180 \mathrm{mEq} / \mathrm{ml}$ kg.

\section{SMALL BOWEL BIOPSY}

Mucosal specimens, obtained by small bowel biopsy, were spread on ground glass slides, immersed in a $10 \%$ formol saline solution, examined under the dissecting microscope, and prepared for conventional light microscopy.

\section{STATISTICAL ANALYSIS}

For data on the duodenal output of pancreatic enzymes and bicarbonate the Kruskal-Wallis

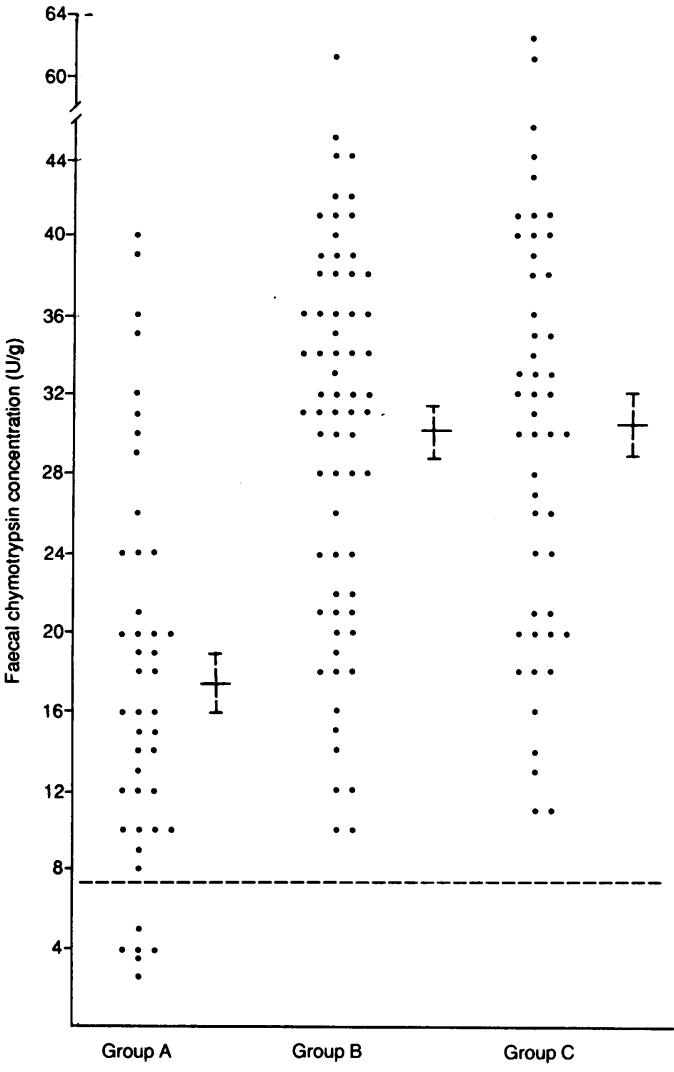

Figure 4: Individual faecal chymotrypsin concentration and mean $(S E)$ values, expressed in units per gram, in the three groups of patients. Group A: coeliac patients with total villous atrophy; group $B$ : coeliac patients with normal intestinal villi; group $C$ : control subjects. Dotted line =low normal limit.

analysis of variance was carried out between the groups of children. Student's $t$ test was used to compare the mean values of faecal chymotrypsin.

\section{Results}

Mean values for the duodenal output of pancreatic enzymes and bicarbonate after secretincaerulein stimulation were within the normal range for our laboratory in the control group and in both the treated and untreated coeliac patients. No significant difference was found between values obtained in the three groups (Table). Stimulated chymotrypsin outputs, however, were below the lower limit of normal in six of the 44 patients with untreated coeliac disease (13.7\%) (Fig 1). Moreover, seven (16\%) and six $(13.6 \%)$ patients with untreated coeliac disease had reduced values respectively of below the lower limit of normal (Figs 2 and 3). Overall, we recorded a reduction in duodenal output in all the enzymes studied in two patients, in chymotrypsin and phospholipase in two patients, in phospholipase and lipase in three patients, in chymotrypsin only in two patients, and in lipase only in one patient. Reduced lipolytic or tryptic activity (or both) was observed in 10 of the 44 untreated coeliac patients $(22 \cdot 2 \%)$, while none of the control subjects nor those in the group with treated coeliac disease had values below the normal limit for all enzyme activities.

Individual stimulated bicarbonate output was within the normal range for our laboratory in the 
control subjects and in treated and untreated coeliac patients.

Figure 4 shows mean and individual values of faecal chymotrypsin in the three groups. It can be seen that mean values were over the lower limit for our laboratory in all groups, but mean values for untreated coeliac patients were significantly lower than the mean values for treated patients $(t=6.444, p<0.0001)$ and control subjects $(t=$ $5 \cdot 743, p<0.0001$ ). Moreover, six patients with untreated coeliac disease had a faecal chymotrypsin value below the lower limit of normal.

\section{Discussion}

Exocrine pancreatic insufficiency has been recognised as accompanying untreated coeliac disease and it has been suggested that a defective release of hormonal factors arising from intestinal mucosa determines reduced pancreatic enzyme secretion..$^{3-5}$ It is known, however, that in malnutrition there is a deficit in pancreatic secretion, ${ }^{1121}$ and since the diagnosis of coeliac disease is often made when patients are severely undernourished, it cannot be excluded that the secretory deficit in this case may not be secondary to a reduced hormone release.

In our study pancreatic function was determined using the secretin-caerulein test thus excluding the possibility that pancreatic function was reduced by hormone stimulation deficit; it can be concluded that in $22 \cdot 2 \%$ of the patients studied with untreated coeliac disease there was reduced secretion of one or more pancreatic enzymes not dependent on the intestinal mucosa damage. Our data, obtained form an extensive patient population, thus confirm the report of Regan and Di Magno in their retrospective study, in which, however, the criteria used to diagnose coeliac disease cannot be considered optimal. ${ }^{6}$

But since it is well known that $10 \%$ of normal pancreatic secretory activity is sufficient to permit normal digestion ${ }^{22}$ and since none of the cases we studied had values below this threshold it must be considered that this pancreatic insufficiency alone does not aggravate the malabsorption that is characteristic of coeliac disease. Furthermore, the significant decrease that we found in mean faecal chymotrypsin, but not in stimulated duodenal chymotrypsin, values in untreated coeliac patients compared with those of the control group confirms that the reduction in endogeneously stimulated pancreatic secretion is greater than that in the potential pancreatic secretory capacity.

As far as the patients with treated coeliac disease are concerned, their pancreatic function determined by both the secretin-caerulein test and faecal chymotrypsin assay seems to be identical to that of the normal control subjects. Moreover, no subject had faecal chymotrypsin values below the normal limit, thus confirming the normalisation of the intestinal hormonepancreatic secretion functional axis and excluding the persistence of secondary insufficiency in pancreatic secretion. These data contradict the reported decrease in pancreatic function when determined by the PABA test in treated coeliac patients. ${ }^{13}$ It must be said, however, that two of the three patients with reduced PABA concentrations among the 18 patients in that study did not have a normal intestinal mucosa and that the determination of urinary PABA excretion can in itself give false positive results. ${ }^{23}$

It can be concluded that apart from the pancreatic secretion insufficiency secondary to a reduced release of cholecystokinin, secretin, and other enterohormones, patients with coeliac disease can also have a pancreatic deficit, most likely due to the state of malnutrition. Furthermore, we also suggest that after a prolonged period on a gluten free diet, and therefore after the normalisation of the intestinal mucosa, no patient with coeliac disease has pancreatic insufficiency.

1 Fernanez LB, De Paula A, Prizont R. Exocrine pancreas insufficiency secondary to gluten enteropathy. Am f Gastroenterol 1960; 53: 464-9.

2 Dreiling DA. The pancreatic secretion in the malabsorption syndrome and related malnutrition states. foumal of the Mount Sinai Hospital 1957; 24: 243-50.

3 Ihse I, Lilja P, Evander A, Skude G. Time-related enzyme concentrations in duodenal aspirates after ingestion of a test concentrations in duodenal aspirates after ingest

$4 \mathrm{Di}$ Magno EP, Go VLW, Summerskill WHJ. Impaired cholecystokinin-pancreozymin secretion, intraluminal dilution, and maldigestion of fat in sprue. Gastroenterology 1972 63: $25-32$

5 Worning H, Mullerty S, Hess Thaysen E, Bang HO. pH and concentration of pancreatic enzymes in aspirates from the human duodenum during digestion of a standard meal in patients with intestinal disorders. Scand $\mathcal{f}$ Gastroenterol 1967; 2: 81-9.

6 Regan PJ, Di Magno EP. Exocrine pancreatic insufficiency in celiac sprue: cause of treatment failure. Gastroenterology 980; 78: 484-7.

7 Maton PN, Selden AC, Fitzpatrick ML, Chadwick US Defective gallbladder emptying and cholecystokinin release in celiac disease. Gastroenterology 1985; 88: $391-6$.

8 Calam J, Ellis A, Dockray GJ. Identification and measurement of molecular variants of cholecystokinin in duodenal mucosa and plasma. F Clin Invest 1982; 69: 218-25.

9 Rhodes RA, Tai HH, Chey WY. Impairment of secretin release in celiac sprue. Dig Dis $S c i$ 1978; 23: 833-9.

10 Kilander AF, Hanssen LE, Gilberg RE. Secretin release in coeliac disease. Scand f Gastroenterol 1983; 18: 765-9.

11 Barbezat GO, Hansen JDL. The exocrine pancreas and protein-calorie malnutrition. Pediatrics 1968 ; 42: 77-92.

12 Bestermann HS, Sarson DL, Johnston DI, et al. Gut-hormone profile in coeliac disease. Lancet 1978; i: 785-8.

13 Collins BJ, Bell PM, Boyd S, et al. Endocrine and exocrine pancreatic function in treated coeliac disease. Pancreas 1986 1: $143-7$.

14 Anonymous. Confirming the diagnosis of coeliac disease [Editorial]. BMF 1975; iv: 2 .

15 Kaspar P, Moller G, Wahlefeld AW, Staehler F. A new photometric method for the determination of chymotrypsin in stool. Z Anal Chem 1982; 311: 391-2.

16 Gullo L, Costa PL, Fontana G, Labo' G. Investigation of exocrine pancreatic function by continuous infusion of cerulein and secretin in normal subjects and in chronic pancreatitis. Digestion 1976; 14: 97-107.

17 Taylor RH, Waterman S. Single intubation test for investigaion of malabsorption and diarrhoea. Gut 1983; 24: 680-2

18 Sarles H, Taulier J, Figarella C. Dosage de la lipase dans le suc duodenal. Revue Françaises Etudes Clinique et Biologie 1963 8: 706-7.

19 Figarella $\dot{C}$, Ribeiro T. The assay of human pancreatic phospholipase in pancreatic juice and duodenal contents. Scand 7 Gastroenterol 1971; 6: 133-7.

20 Figarella C, Souville C, Quet O, et al. Problemes poses par le dosage des enzymes pancreatiques dans le suc duodenal. Vie Médicale 1966; 47: 493-500.

21 Sauniere JF, Sarles H, Attia Y, et al. Exocrine pancreatic function of children from the Ivory Coast compared to French children. Effect of kwashiorkor. Dig Dis Sci 1986; 31: 481-6.

$22 \mathrm{Di}$ Magno EP, Go VLW, Summerskill WHJ. Relations between pancreatic enzyme outputs and malabsorption in severe pancreatic insufficiency. $N$ Engl $\mathcal{F}$ Med 1973; 288: 813-5. 23 Lankish PG. Exocrine pancreatic function tests. Gut 1982; 23: 